\title{
Adaptive hypermedia system in times of COVID-19: Application in Management Accounting course 1 at the University of Havana.
}

\author{
Carlos Javier Mas López ( $\square$ carlosm@fcf.uh.cu ) \\ University of Havana https://orcid.org/0000-0003-1284-6444 \\ Inés María González Vidal ( $\square$ inesmaria.gonzalez@rai.usc.es) \\ University of Santiago de Compostela https://orcid.org/0000-0003-0559-0321 \\ Gissell Labrada Balmaseda \\ University of Havana https://orcid.org/0000-0002-0592-9535
}

\section{Research Article}

Keywords: University, hypermedia adative systems, personalization, academic performance, student, Management Accounting I

Posted Date: June 28th, 2021

DOI: https://doi.org/10.21203/rs.3.rs-651357/v1

License: (c) (i) This work is licensed under a Creative Commons Attribution 4.0 International License. Read Full License 


\section{Abstract}

New trends in higher education, accentuated by the global COVID19 pandemic, visualize the need for more flexible virtual courses. The Faculty of Accounting and Finance of the University of Havana, analyzes new technological configurations that facilitate the personalization of the educational process. In this context, this work aims to design an adaptive hypermedia system prototype applied to the Management Accounting 1 course at the University of Havana to guarantee the delivery, distribution, and variety of learning content to students in a personalized way.

An empirical research supported by an experimental method is presented, with a sample of 94 students, a Control Group made up of 41 students and an Experimental Group made up of 53 students; Descriptive statistics and the Pareto principle support the results. It is concluded that, 1. The personalization of the educational process through the application of adaptive techniques leads to academic success at an individual and group level, in this sense, the Experimental group only needed a final exam session compared to the three calls of the group of control; 2. Need to continue investigating new adaptation criteria, in this sense, the mean scores obtained by the Experimental group did not have a significant increase in relation to that of the Control group. This work also contributes to visualizing educational equity referring to the capacity of the educational system to offer special supports that guarantee that educational objectives are achieved in a broader dimension; innovation is related to technologies and new strategies to optimize online educational processes.

\section{Introduction}

Latin America and the Caribbean is one of the regions of the world most affected by the global pandemic produced by COVID-19, which has impacted the educational system, transferring it to virtual contexts (Gigliotti, 2021; Popa, 2020; Yang \& Huang, 2021). The development of new advanced technologies applied in university teaching (and at all educational levels) reaffirms the need to incorporate new dynamics in the classroom (Goodyear, Carvalho, Yeoman, Castañeda \& Adell, 2021; Rodríguez, Cantabrana \& Cervera, 2021). In this sense, virtual learning environments and recommendation systems have been gaining ground as essential components in educational applications (Marienko, Nosenko, \& Shyshkina, 2020).

Also, in the light of several recent investigations, the challenges, and possibilities of educational equity in the image of innovations as creation, could relocate innovation as the dynamics experienced in the educational process; but innovation is never a complement to existing practice, shapes it, and with unforeseen consequences (Hall \& Lulich, 2021; Nichols, 2020). Innovation is related to technologies and new strategies to optimize educational processes in line with the demands of society (Selwyn, 2016). The term equity in education refers to the capacity of the educational system to consider the situation of inequality among students and in their family and social environment, it also refers to how these special supports are offered; so that the educational objectives reach a broader dimension (Copridge, Uttamchandani \& Birdwell, 2021; Jiménez \& González, 2021).

In this framework, personalized learning has the potential to transfer the approach of teacher-centered learning to student-centered environments (de Benito, García \& Moral, 2020). Modern online learning systems can be based on the flexible conception of adaptive hypermedia systems or on a data-driven conception, both conceptions currently have great potential and constitute a form of personalized learning experiences, helping teachers and students to create, manage and improve the online educational process (Espinosa Pérez, Espinosa Posso, Gaviria Loaiza \& Ramírez Parra, 2020, Howlin \& Lynch, 2014; Ruiz-Palmero, López-Álvarez \& Sánchez-Rivas, 2021).

Adaptive hypermedia systems applied to education offer the opportunity for a personalized environment adapted to the individual characteristics of students (Brusilovsky \& Maybury, 2002; Qodad, Benyoussef, El Kenz, \& Elyadari, 2020). The student has access to information relevant to him, through hyperlinks and according to the level of knowledge, objectives, and skills of the user; therefore, adaptive hypermedia systems incorporate a student-centered teaching approach that meets the individual needs of students (Reigeluth et al., 2015).

The implementation of recommender systems is an essential component in adaptive hypermedia applications for educational purposes, guaranteeing relevant hyperlinks for students, and thus reducing the student's cognitive effort (Erümit \& Çetin, 2020). But the great challenge of adaptive and personalized hypermedia systems is the automatic detection of students' needs. In this sense, some systems have managed to develop tools that detect learning styles and affective states from interactions with the system (Khan, Weippl \& Tjoa, 2009, Troussas, Chrysafiadi \& Virvou, 2020).

Adaptive hypermedia systems are characterized by a hypertext and hypermedia system, it must include a user model and a domain model, in addition the system must be adjustable using the adaptive model (Osadcha, Osadchyi, Semerikov, Chemerys, \& Chorna, 2020).

The identification of the personal characteristics of each student is achieved with the user's modeling technology (Weippl \& Tjoa, 2009). Adaptive systems are distinguished by modeling the characteristics of the user (students); hence the system solves problems and performs a Loading [MathJax]/jax/output/CommonHTML/fonts/TeX/fontdata.js re in adaptive hypermedia environments. 
In this scenario, this work aims to design an adaptive hypermedia system prototype applied to the Management Accounting 1 course at the University of Havana, to guarantee the delivery, distribution, and variety of learning content to students in a personalized way. To achieve these objectives, an experimental methodological design followed those answers research questions that are detailed in the Materials and Methods section. This work contributes, among other issues, to visualize new configurations to achieve the academic success of students in virtual learning-learning environments.

\subsection{Characterization of the Management Accounting course 1}

The Management Accounting course 1 is a basic subject in the Accounting and Finance Degree and belongs to the "E Curriculum". It is taught in the third year of the degree with 60 contact hours.

The study of the Management Accounting 1 subject offers the student the necessary elements to understand the role of costs in the administration and Political Economy process, providing the theoretical foundations of cost as an economic category (Horngren, Sundem \& Stratton, 2007). The starting point of the subject is to highlight its link with financial accounting and establish the interrelation between both disciplines (Horngren, 1977). The course explains the basic terminology and considers the definitions of costs and expenses essential (López, 2010). It defines the different classifications that are fundamental for its vertical integration with the other subjects of the discipline. The purposes of cost accounting for managerial purposes are explained, highlighting its importance within the business strategy (Polimeni \& Kole, 2001). The essential contents focus on cost systems, planning and decision-making, based on the behavior of costs and their use by organizations (Horngren, Foster \& Datar, 2007).

\subsection{The Moodle platform as a virtual teaching-learning environment}

The term virtualization of education refers to the representation in virtual spaces of educational processes and objects, associated with teaching and learning activities, research and management (Dafonte-Gómez, Fabián Maina \& García-Crespo, 2021; Poce \& Appenduni, 2021). For this, a didactic transformation of the subjects is required using virtual resources, in addition to a pedagogical guide that stimulates the strengthening of the development of new digital skills (Reyes \& Martínez, 2021).

The University of Havana has implemented its subjects in a Virtual Teaching-Learning Environment, using Moodle as a virtual platform. This educational alternative is characterized by maintaining the current axiological elements, the identity, and the interest of the exchange of knowledge both teachers and students (Estrada Molina \& Fuentes Cancell, 2021).

Some recent research visualizes the need for educational innovation to improve teacher management on the Moodle platform (Pomares Bory, Arencibia Flores and Galvizu Díaz, 2021). The perception of teachers about the digital knowledge of university teaching staff in virtual environments reveals its use basically as a repository of information and evaluation, in addition to the fact that there is a low connection speed for work on the platform, and the lack of clarity in the instructions received to carry out the tasks (Flores \& Díaz, 2021).

Other results show an average level in the development of digital competence in the university context of teaching practice and relate it to the availability of network technologies and services; suggest the existence of a correlation between the didactic dimension and the personal dimension that indicates that teachers who implement didactic strategies with the use of ICT show greater use and access to ICT in their daily lives and positively value digital tools to integrate in teaching and learning processes (Gutiérrez-Castillo, 2021).

In this sense, the country's digitization opportunities are affected by the availability, high cost, and quality with which Internet access infrastructure services are provided from home (Triana Cordoví \& Galeano Zaldívar, 2020). These factors strongly contribute to the persistence of digital gaps that translate into social gaps.

\section{Related Words}

The main characteristic of a flexible education is the adaptation of learning to the needs and circumstances of the students (Mwando, Issa \& Kangotue, 2021; Vitali, Blackmore \& Bakeberg, 2021). In this sense, at present, intelligent learning environments based on the user model have increased (Espinosa Pérez, Espinosa Posso, Gaviria Loaiza \& Ramírez Parra, 2020). The user model contains the student's characteristics related to cognitive, behavioral, and emotional variables; its design constitutes a fundamental element for the personalization of educational virtual environments (Qodad, Benyoussef, El Kenz, \& Elyadari, 2020).

Loading [MathJax]/jax/output/CommonHTML/fonts/TeX/fontdata.js 
Educational data mining techniques support automated searches and the emergence of new models of metacognition, motivation, and affectivity (Desmarais \& d Baker, 2012). As more student data becomes available, the methods for exploiting it improve (Savage, Arif, Smoke, \& Farrell, 2017). There are designs of models of affective users that consider the emotional states of the student, that is, that allow the probabilistic combination of information about the causes and effects of emotional reactions (Conati \& Maclaren, 2009).

Also, the creation of a domain model is fundamental in an adaptive hypermedia system, since it defines the relationships between concepts within an adaptive educational environment (Chau, Labutov, Thaker, He, \& Brusilovsky, 2020). The domain model must guarantee the presentation of these contents in various formats, considering the different presentation styles of the domain model; all these elements will contribute to the success of the experience (Howlin \& Lynch, 2014).

Adaptive hypermedia systems for education combine a set of technologies to offer the student recommendations appropriate to their needs (El Janati \& Maach, 2017). The adaptation model is based on the information contained in the user model and relates it to the domain model, in this way it generates adaptations referring to content suggestions, in different formats, styles or learning contexts (DeCoux, 2016).

The adaptation can be presented in various ways (figure 1), for example the navigation adaptation manipulates the links, that is, it hides, orders, or highlights them (Rossi, Pastor, Schwabe and Olsina, 2007). The system guarantees relevant hyperlinks for the user, thus reducing the student's cognitive effort (Erümit \& Çetin, 2020). This process helps the student to orient himself in hyperspace, the same link can take users to different web pages. On the other hand, presentation adaptation is related to the form of the content accessed.

Content adaptation provides the user with access to content based on their profile, preferences, and learning style (Khan, Weippl \& Tjoa, 2009). In another sense, collaborative adaptation allows communication between all the actors in the educational process through social media applications (Torrijos, Bellogín \& Sánchez, 2020). Context adaptation allows the tool to meet the requirements of the user's environment, which can be mobile, tablet or PC (Brusilovsky, 2004).

Some studies reveal the importance of making adaptations according to the gender of the student; it has been observed that female and male students respond differently to cognitive and affective support (Vail, Boyer, Wiebe \& Lester, 2015). The advantages of a gender approach in adaptive hypermedia systems can improve gender differences in relation to the learning style and use of the system, the motivational educational goals, the cognitive and affective needs of the student, as well as the impact of the interventions of pedagogical agents.

Although recent studies did not find significant differences in the essential skills in the use of ICT among adolescents according to their gender, so that they participate efficiently in a modern society (Gnambs, 2021). However, other scientific findings revealed that gender differences have a considerable effect on academic performance; consequently, it is necessary to consider its influence on the development of personalized virtual learning environments, as it allows the system to be more powerful to meet the specific requirements related to the behavior and learning experience of women and men (Wongwatkit, Panjaburee, Srisawasdi, \& Seprum, 2020).

The Internet and applied ICTs in education have contributed to increasing the interest and instructional practices based on game-based learning (Martin, Dennen \& Bonk, 2020). Adaptive gamification in education has been very present in recent years; In this sense, some works pointed out the need for new learning models that delve into dynamic adaptation methods to allow the system to better adapt to the student's behavior; Also, the need to increase research that deepens the impact of these gamified adaptive systems on students and education in general (Hallifax, Serna, Marty \& Lavoué, 2019).

Other results reaffirm the importance of the analysis of the user model in the gamification processes; these systems link the elements of the game to the characteristics of the student (Klock, Gasparini, Pimenta \& Hamari, 2020). The use of game elements in educational settings increases motivation for the suggested content and causes positive effects on the cognitive, affective, and academic performance of students (Deterding, Sicart, Nacke, O'Hara \& Dixon2011). The adaptation strategies and the proposal of a new taxonomy for the adaptation of gamification elements, show the adaptability of the design and the gamification strategies in educational environments is a promising field of research (Ayastuy, Torres \& Fernández, 2021).

\section{Materials And Methods}

This work aims to design a prototype of an adaptive hypermedia system applied to the Management Accounting 1 course at the University of Havana, to guarantee the delivery, distribution, and variety of learning content to students in a personalized way. To achieve this, a set of Related Works was reviewed; Then, the prototype design consisted of two stages, first the conceptual design of the system where the following scientific questions are answered and then the testing stage, the following scientific questions were answered.

Q1: What is the conceptual architecture of an adaptive system like?

Loading [MathJax]/jax/output/CommonHTML/fonts/TeX/fontdata.js em? 
Q3: How is the gender approach addressed in the system? and Q4: What are the gamification elements that can be included in the proposal? These two questions are addressed in the text in a preliminary way and will be analyzed and evaluated in future in-depth research.

Q5: What are the characteristics of the adaptive model?

Based on an experimental design, a period of two semesters was evaluated in which a total of 94 students participated, who interacted with the Moodle platform. The Control group consisted of 53 students, who interact in a virtual environment through the Moodele platform but do not participate in adaptive experiences. The Experimental Group formed by 41 students who participate in an adaptive experience. At this stage, the following scientific questions were answered.

Q6: How does academic performance behave in both groups? Descriptive statistics support the results.

Q7: How is the Pareto principle interpreted in this case? The Pareto diagram is used as a tool for the analysis of the quality of the proposal that uses adaptive hypermedia techniques, in this way, priority can be given to educational situations that must be addressed with greater urgency, as is the case of different approaches to achieve personalization in education and its influence on academic performance.

\section{Result}

\subsection{Conceptual architecture of an Adaptive System (Q1)}

The design of a system prototype that incorporates adaptive techniques is carried out. This refers to the ability to create profiles and stereotypes of students based on an adaptive architecture fundamentally linked to the professional interests of students. It is applied to students of the face-to-face study modality so that they can access the activities of the online course.

The hypermedia content structure allows reducing student interactions in hyperspace by showing only the most relevant links for the course. The adaptations made by the system are linked: to the professional interests of the students, a gender approach, returns of aid that the system makes, and the analysis of the student's progress through the contents of the subject. To improve the teaching process, theoretical and practical lessons are integrated in the same activity with the use of the laboratory and the Moodle tool of the UH.

Figure 2 represents a conceptual architecture, various elements of the system are shown, for example: the domain model and the user model, which are stored in system databases; the adaptive model and the adaptation rules that will depend on the user's interactions with the system (bin Rodzman, Bakar, Choo, Aljunid, Ismail, Abd Rahman \& Rosli, 2020, Liu, Browne \& Xue, 2021). SOA is a style of IT architecture that represents the nexus of the objectives of the system with the software system; these designs gain strength in recent educational implementations (Niknejad, Ismail, Ghani, Nazari and Bahari, 2020).

\subsection{Domain Model (Q2)}

The design of the activity proposals must consider the number of exercises already solved correctly by the student. The system must be able to readjust and provide levels of complexity in the task according to the demands of the student. This new design required a new domain model approach that considers parameters that imply changes in the level of complexity of the tasks proposed to students by the system.

Figure 3 shows an example of a domain model to which different levels of complexity can be associated. This scheme provides different levels of Context, each pair < Ci, Lij> is associated with subdomains with the curriculum linked to a level of complexity "Lij", that is, the vectors $\mathrm{Vij}(\mathrm{Ci}$; Lij) constitute a relationship between the different learning contexts, in this case they are different concepts (or tasks) and levels of complexity that the system must provide. From this scheme, we have an approach that implies changes in the student's model in three essential elements: level of complexity, different domains, and the curricular vector.

\subsection{Gender approach and use of gamification (Q3 \& Q4)}

A preliminary character is presented in the design, considerations of a gender approach that incorporates gamification elements, however, these elements and their application results do not constitute a fundamental objective in this experience and will be addressed in future works.

1. Gender approach (Q3): Based on previous studies on the influence of gender in virtual and personalized learning environments, it was proposed to promote greater affective and cognitive returns of the system, through motivational and explanatory phrases to the students;

Loading [MathJax]/jax/output/CommonHTML/fonts/TeX/fontdata.js 
while male students received cognitive and motivational support through the discreet use of gamification elements as a reward (Wongwatkit, Panjaburee, Srisawasdi \& Seprum, 2020).

2. Use of gamification (Q4): The gamification elements will be made up of three interrelated elements, the dynamics, the mechanics, and the components of the system. The dynamics will be related to the behavior of the student in their interaction with the platform, this will affect a previously designed reward system. Mechanics will represent the basic components of the course, such as adaptation rules and their operation. The main mechanism that stimulates the above dynamics is the accumulation of points for carrying out the activities, which will have repercussions in an escalation of levels and new challenges of increasingly complex activities (Ayastuy, Torres \& Fernández, 2021, Deterding, Sicart, Nacke, 0 'Hara and Dixon, 2011, Klock, Gasparini, Pimenta \& Hamari, 2020)

\subsection{Adaptive model and rule-based mechanism (Q5)}

Figure 4 shows the basic scheme for the analysis of the adaptation rules. In this sense, to generate adequate adaptation rules, it was necessary to analyze the student's interactions with the system, in relation to various elements, namely: the return of the response to affective and cognitive support; the level of progress, the quantity and complexity of the tasks solved. The first rules will be generated by the teacher, considering the students' stereotypes, in subsequent courses and analyzing the system data and using data mining software, automatic rules will be generated that should enrich future proposals (Liu, Browne \& Xue, 2021).

\subsection{Descriptive statistics (Q6)}

Of a total sample of 94 students, a female representation of $57.4 \%$ is visualized compared to $42.6 \%$ of male students. These values are consistent with the historical values of this career at the faculty level, where female representation is relatively higher.

Table 1 Summary frequency table. By authors with LibreOffice.

\begin{tabular}{lllll} 
& Control group & \multicolumn{2}{l}{ Experimental group } \\
\cline { 2 - 5 } Score & Female students & Male students & Female students & Male students \\
\hline 5 & 4 & 4 & 7 & 3 \\
\hline 4 & 6 & 7 & 8 & 8 \\
\hline 3 & 13 & 5 & 15 & 12 \\
\hline 2 & 1 & 1 & 0 & 0
\end{tabular}

Note: Scores 5 excellent, 4 good, 3 regular and 2 insufficient

To summarize, describe, and calculate basic parameters about the data set, we rely on descriptive statistics. It is observed that the Experimental group only needed a $1 \mathrm{st}$ call for the final exam compared to the $3 \mathrm{rd}$ call of the Control group. The mean of the Experimental group was 3.68 slightly higher than the 1 st call of the control group 3.44, that is, the effectiveness of the adaptations made should continue to be investigated, in order to raise the average of scores at the group level more significantly. . The standard error in the Experimental group 0.11 was slightly less than that of the Control group 0.15 , this parameter shows the variability of the sample means by its standard deviation. The mode, median and distribution of the statistical data by quartiles was the same in the 1st call in both groups. The distribution of the statistical data by quartiles was the same in both groups in the 1 st call; the first quartile or lower quartile is the value of the variable such that a quarter, that is, $25 \%$ of the observations are less than or equal, the third quartile $75 \%$ of the data is less than or equal to this value. The variance represents a measure of dispersion, that is, the variability of a series of data with respect to its mean, in this case the Experimental group presented the lowest values 0.61 if we compare the 1 st calls in both groups. The standard deviation is a measure of the degree of dispersion of the data with respect to the average value, the Experimental group presented the lowest values 0.78 if we compare the 1 st calls in both groups. The intervals group the values that have the same frequency amplitude. Upper and lower values of the interval observed in table 1 for each group.

Table. 2 Descriptive statistics 


\begin{tabular}{lllll} 
& \multicolumn{2}{l}{ Control Group } & Experimental group \\
\cline { 2 - 3 } & 1st call & 2nd call & 3rd call & 1 st call \\
\hline Mean & 3.44 & 2.5 & 3.75 & 3.68 \\
\hline Standard error & 0.15 & 0.22 & 0.75 & 0.11 \\
\hline Mode & 3 & 2 & 5 & 3 \\
\hline Median & 3 & 2.5 & 4 & 3 \\
\hline 1st quartile & 3 & 2 & 2.75 & 3 \\
\hline 3rd quartile & 4 & 3 & 5 & 4 \\
\hline Variance & 0.9 & 0.3 & 2.25 & 0.61 \\
\hline Standard deviation & 0.95 & 0.55 & 1.5 & 0.78 \\
\hline Intervals & 3 & 1 & 3 & 2 \\
\hline Lower values & 2 & 2 & 2 & 3 \\
\hline Higher values & 5 & 3 & 5 & 5 \\
\hline Sum & 141 & 15 & 15 & 195 \\
\hline Count & 41 & 6 & 4 & 53 \\
\hline Studio & & & & \\
\hline
\end{tabular}

Note: By authors with RapidMiner Studio.

In figure 5 it is observed that the box corresponding to the experimental group does not present the lower line that extends from the box, this indicates that there is no variability outside the quartiles in the lower part. Symmetry is assumed for whiskers and normality for their length; the spaces between the different parts of the table indicate the degree of dispersion and skewness of the data and no outliers are shown.

The figure 5 also makes it possible to visually estimate various $L$ estimators, in particular the interquartile range. In short, the figure relates the academic performance of the student in the Control and Experimental groups, and it is observed that the Experimental group did not have disapproved students, this result suggests that the virtual activities proposed through adaptive techniques influenced better results related to academic performance.

\subsection{Pareto principle (Q7)}

Figure 6 represents the Pareto principle, which is a technique that allows information to be classified graphically according to its relevance, it also allows prioritization and thus facilitates the study of various phenomena, in this case, the principle is applied to an educational phenomenon. The objective that is intended is to visualize through the Pareto diagram the ability to prioritize decision-making within the educational process, as well as to evaluate the percentage of all failures and to know if they can be better resolved or avoided. Although it is worth highlighting the reduced number of data, in this case with the help of the RapidMiner Studio tool, it is confirmed that if content adaptations corresponding to $57.14 \%$ of the total are made in a virtual course, the results show a success corresponding to the $100 \%$.

\section{Discussion}

The General Accounting 1 course introduces the student to the accounting universe, it is characterized by presenting the student with a large volume of new and complex concepts. The Moodle platform as virtual learning environments offers the opportunity to manage online courses with novel configurations (Flores \& Díaz, 2021, Pomares Bory, Arencibia Flores \& Galvizu Díaz, 2021).

In this sense, the design of a prototype of the adaptive hypermedia system on a Moodle platform, allowed students to have access to personalized and relevant content for the course, in such a way that the cognitive effort was reduced and thus contributing to the success of the course. educational process (Ayastuy, Torres \& Fernández, 2021). The use of adaptive techniques also made it possible to exploit new domain, adaptation, and user (student) models that guaranteed a content proposal that was considered, namely: the return of the response to affective and cognitive support; the level of progress, the quantity and complexity of the tasks solved. In this way, more complex activities are proposed for students who had a more advanced trajectory and reaffirmation content and less complex in other cases (Erümit \& Çetin, 2020; Marienko, Nosenko \& Shyshkina, 2020; Osadcha, Osadchyi, Semerikov, Chemerys \& Chorna, 2020; Qodad, Benyoussef, El Kenz \& Elyadari, 
In short, the experiment carried out outlines the essential elements that facilitate the personalization of the educational process through adaptive hypermedia techniques, which involve changes in the domain model in three essential elements, level of complexity, different domains, and the curricular vector. Hypermedia's content structure will reduce student interactions in hyperspace by displaying only the links most relevant to the course. The considerations of a gender approach that incorporates gamification elements were presented in a preliminary way in the design and will be the focus of attention in future works. The study confirmed the historical values in the Accounting and Finance Bachelor's degree and present in the General Accounting course 1 referring to the largest number of female representatives. Finally, it was confirmed that with a design that uses adaptive hypermedia techniques, less dispersed academic performance is observed (there were no disapproved students in the Experimental group)

\section{Conclusion}

The social distancing caused by the Covid-19 pandemic affected all areas of society, including education systems. Educational institutions to keep education running, had to quickly adapt to the situation. In Latin America and the Caribbean, as in the entire planet, the urgency of a transformation from face-to-face classes to online courses was evident. And in this context, this work shows equity in education as an adaptive proposal that offers content adapted to the individual characteristics of students, and that is related to innovation in education, which means that all students must have the same opportunity to access all tools and resources that are linked to the purpose of student learning. The adaptive hypermedia system guarantees the delivery, distribution, and variety of learning content to students in a personalized way. The literature review visualized that in Cuba there are digital and social gaps caused by the lack of digital infrastructure at home. In this sense, current technological advances should represent an opportunity to acquire less expensive equipment that allows ubiquity and guarantees remote access to the virtual teaching-learning system. Finding new ways to increase motivation and achievement in school are age-old challenges for teachers and the education system, a prerequisite for student academic success.

\section{Declarations}

\section{Acknowledgment}

Thanks to the Department of Costs and Information Systems of the Accounting Office of the Faculty of Accounting and Finance of the University of Havana and to the research project "Contributions of Higher Education to Accounting and the Cuban Economy". The funds and resources correspond to the UH - University of Havana. Thanks to the Equity and Innovation doctoral program of the USC - University of Santiago de Compostela.

\section{Author Contributions}

For the sake of transparency, we encourage authors to submit an author declaration file describing their individual contributions to the article using the relevant CRediT roles:

1. Inés María González Vidal in Conceptualization; Data curation; Formal analysis; Investigation; Software; Roles / Writing: original draft and editing.

2. Carlos Javier Más López in: Methodology; Supervision; Validation; Monitor; Writing: review.

3. Gissell Labrada Balmaseda in Conceptualization; Formal analysis; Roles / Write Validation.

\section{Availability Of Data, Material And Code Availability}

' The authors agree to make the necessary data available '.

\section{Submission Declaration and Verification}

' This article has not been previously published '.

\section{Declaration Of Interest and Consent To Publish}




\section{A statement of ethics approval}

TheethicscommieeoftheFactyoftheFactyofAount $\in g$ and $F \in$ anceoftheUniversityofHavana $\in$ dicatestheapprovalofthestudy

\section{References}

Ayastuy, M. D., Torres, D., \& Fernández, A. (2021). Adaptive gamification in Collaborative systems, a systematic mapping study. Computer Science Review, 39, 100333. https://doi.org/10.1016/j.cosrev.2020.100333.

bin Rodzman, S. B., Bakar, N. A., Choo, Y. H., Aljunid, S. A., Ismail, N. K., Abd Rahman, N., \& Rosli, M. M. (2020). I-ONAr: A rule-based machine learning approach for intelligent assessment in an online learning environment. Indonesian Journal of Electrical Engineering and Computer Science, 17(2), 1021-1028. https://doi.org/110.11591/ijeecs.v17.i2.pp1021-1028

Brusilovsky, P., \& Maybury, M. T. (2002). From adaptive hypermedia to the adaptive web. Communications of the ACM, 45(5), 30-33. https://doi.org/10.1145/506218.506239.

Brusilovsky, P. (2004). Adaptive navigation support: From adaptive hypermedia to the adaptive web and beyond. PsychNology Journal, 2(1), 723.

Chau, H., Labutov, I., Thaker, K., He, D., \& Brusilovsky, P. (2020). Automatic concept extraction for domain and student modeling in adaptive textbooks. International Journal of Artificial Intelligence in Education, 1-27. https://doi.org/10.1007/s40593-020-00207-1.

Conati, C., \& Maclaren, H. (2009, June). Modeling user affect from causes and effects. In International Conference on User Modeling, Adaptation, and Personalization (pp. 4-15). Springer, Berlin, Heidelberg. https://doi.org/10.1007/978-3-642-02247-0_4.

Copridge, K. W., Uttamchandani, S., \& Birdwell, T. (2021). Faculty Reflections of Pedagogical Transformation in Active Learning Classrooms. Innovative Higher Education, 46(2), 205-221.

de Benito, B., García, J. M., \& Moral, S. V. (2020). Entornos tecnológicos en el codiseño de itinerarios personalizados de aprendizaje en la enseñanza superior. Edutec. Revista Electrónica De Tecnología Educativa, (74), 73-93. https://doi.org/10.21556/edutec.2020.74.1843.

Dafonte-Gómez, A., Fabián Maina, M., \& García-Crespo, O. (2021). Uso del smartphone en jóvenes universitarios: una oportunidad para el aprendizaje. Pixel-Bit, Revista de Medios y Educacion, (60). https://doi.org/10.12795/pixelbit.76861

DeCoux, V. M. (2016). Kolb's learning style inventory: A review of its applications in nursing research. Journal of Nursing Education, 29(5), 202207. https://doi.org/10.3928/01484834-19900501-04.

Desmarais, M. C., \& d Baker, R. S. (2012). A review of recent advances in learner and skill modeling in intelligent learning environments. User Modeling and User-Adapted Interaction, 22(1-2), 9-38. https://doi.org/10.1007/s11257-011-9106-8 .

Deterding, S., Sicart, M., Nacke, L., O'Hara, K., \& Dixon, D. (2011). Gamification. using game-design elements in non-gaming contexts. In CHI'11 extended abstracts on human factors in computing systems (pp. 2425-2428). https://doi.org/10.1145/1979742.1979575.

El Janati, S., \& Maach, A. (2017, April). Towards a new adaptive E-learning framework for adapting content to presentation. In 2017 Intelligent Systems and Computer Vision (ISCV) (pp. 1-7). IEEE. https://doi.org/10.1109/ISACV.2017.8054970.

Erümit, A. K., \& Çetin, i. (2020). Design framework of adaptive intelligent tutoring systems. Education and Information Technologies, 25(5), 4477-4500. https://doi.org/10.1007/s10639-020-10182-8.

Espinosa Pérez, Y. A., Espinosa Posso, C. P., Gaviria Loaiza, J., \& Ramírez Parra, C. J. (2020). Puntos a favor y en contra de la educación flexible en el proceso de enseñanza-aprendizaje. http://hdl.handle.net/10823/2004.

Estrada Molina, O., \& Fuentes Cancell, D. R. (2021). Resultados de la capacitación semipresencial a profesores y tutores de la práctica profesional. Revista Cubana de Educación Superior, 40(1). 
Flores, L. G. A., \& Díaz, K. G. (2021). Innovación emergente para la COVID-19: taller virtual sobre el uso educativo de la plataforma Moodle. Revista Cubana de Informática Médica, 1(1), 438.

Gigliotti, R. A. (2021). The Impact of COVID-19 on Academic Department Chairs: Heightened Complexity, Accentuated Liminality, and Competing Perceptions of Reinvention. Innovative Higher Education, 1-16.

Gnambs, T. (2021). The development of gender differences in information and communication technology (ICT) literacy in middle adolescence. Computers in Human Behavior, 114, 106533. https://doi.org/10.1016/j.chb.2020.106533..

Gutiérrez-Castillo, J. J. (2021). Presentation: Digital innovation in education. Innovación digital en educación. EDMETIC, 10(1), I-III. https://doi.org/10.21071/edmetic.v10i1.13179.

Goodyear, P., Carvalho, L., Yeoman, P., Castañeda, L., \& Adell, J. (2021). Una herramienta tangible para facilitar procesos de diseño y análisis didáctico: Traducción y adaptación transcultural del Toolkit ACAD. Pixel-Bit, Revista de Medios y Educacion, (60).

https://doi.org/10.12795/pixelbit.84457.

Hall, R., \& Lulich, J. (2021). University Strategic Plans: What they Say about Innovation. Innovative Higher Education, 1-24.

Hallifax, S., Serna, A., Marty, J. C., \& Lavoué, É. (2019, September). Adaptive gamification in education: A literature review of current trends and developments. In European Conference on Technology Enhanced Learning (pp. 294-307). Springer, Cham. https://doi.org/10.1007/978-3-03029736-7_22.

Horngren,C.T.(1977). Contabilidad de Costos. Un enfoque de gerencia.Editorial Prentice/Hall Internacional, Cuarta edición.

Horngren, C. T., Foster, G., \& Datar, S. M. (2007). Contabilidad de costos un enfoque gerencial. Pearson educación.

Horngren, C. T., Sundem, G. L., \& Stratton, W. O. (2007). Contabilidad administrativa. Pearson educación.

Howlin, C., \& Lynch, D. (2014, November). A framework for the delivery of personalized adaptive content. In 2014 International Conference on Web and Open Access to Learning (ICWOAL) (pp. 1-5). IEEE.10.1109/ICWOAL.2014.7009203.

Jiménez, M. G. L., \& González, M. L. G. (2021). Significados y prácticas docentes en torno a la equidad en aulas normalistas. Revista Panamericana de Pedagogía, (31).

Khan, F. A., Weippl, E. R., \& Tjoa, A. M. (2009, June). Integrated approach for the detection of learning styles and affective states. In EdMedia+ Innovate Learning (pp. 753-761). Association for the Advancement of Computing in Education (AACE).

https://www.learntechlib.org/primary/p/31584/.

Klock, A. C. T., Gasparini, I., Pimenta, M. S., \& Hamari, J. (2020). Tailored gamification: A review of literature. International Journal of HumanComputer Studies, 102495. https://doi.org/10.1016/j.ijhcs.2020.102495.

Liu, Y., Browne, W. N., \& Xue, B. (2021). Visualizations for rule-based machine learning. Natural Computing, 1-22. https://doi.org/10.1007/s11047-020-09840-0.

López, M. colectivo de autores (2010) Sistemas de costos. Editorial “Félix Varela“. Habana.

Marienko, M., Nosenko, Y., \& Shyshkina, M. (2020). Personalization of learning using adaptive technologies and augmented reality. https://arxiv.org/abs/2011.05802.

Martin, F., Dennen, V. P., \& Bonk, C. J. (2020). A synthesis of systematic review research on emerging learning environments and technologies. Educational Technology Research and Development, 68(4), 1613-1633.https://doi.org/10.1007/s11423-020-09812-2.

Mwando, S. M., Issa, A., \& Kangotue, V. (2021). Staff and students' perception of implementing flexible working arrangements in institution of higher education. Journal of Facilities Management. https://doi.org/10.1108/JFM-07-2020-0040.

Nabizadeh, A. H., Leal, J. P., Rafsanjani, H. N., \& Shah, R. R. (2020). Learning Path Personalization and Recommendation Methods: A Survey of the State-Of-The-Art. Expert Systems with Applications, 113596. https://doi.org/10.1016/j.eswa.2020.113596.

Nichols, T. P. (2020). Innovation from below: Infrastructure, design, and equity in literacy classroom makerspaces. Research in the Teaching of English, 55(1), 56-81.

Loading [MathJax]/jax/output/CommonHTML/fonts/TeX/fontdata.js 
Niknejad, N., Ismail, W., Ghani, I., Nazari, B., \& Bahari, M. (2020). Understanding Service-Oriented Architecture (SOA): A systematic literature review and directions for further investigation. Information Systems, 91, 101491. https://doi.org/10.1016/j.eswa.2020.113596.

Osadcha, K., Osadchyi, V., Semerikov, S., Chemerys, H., \& Chorna, A. V. (2020). The review of the adaptive learning systems for the formation of individual educational trajectory. In CEUR_Workshop Proceedings (Vol. 2732, pp. 547-558). http://ceur-ws.org/Vol-2732/20200547.pdf.

Poce, A., \& Amenduni, F. (2021). OpenVM MOOCs: a design for self-regulated learning. Edutec. Revista Electrónica De Tecnología Educativa, (75), 31-49. Poce, A., \& Amenduni, F. (2021). OpenVM MOOCs: a design for self-regulated learning. Edutec. Revista

Electrónica De Tecnología Educativa, (75), 31-49. https://doi.org/10.21556/edutec.2021.75.1971.

Pomares Bory, E. D. J., Arencibia Flores, L. G., \& Galvizu Díaz, K. (2021). Percepción profesoral sobre una innovación educativa para mejorar la gestión docente utilizando la_plataforma Moodle. EDUMECENTRO, 13(1), 167-183._http://orcid.org/0000-0003-3237-9070.

Popa, S. Reflections on COVID-19 and the future of education and learning. Prospects 49, 1-6 (2020). https://doi.org/10.1007/s11125-02009511-z

Polimeni, R. S., \& Kole, M. A. (2001). Contabilidad de costos: Conceptos y aplicaciones para la toma de decisiones gerenciales. McGraw-Hill.

Qodad, A., Benyoussef, A., El Kenz, A., \& Elyadari, M. (2020). Toward an Adaptive Educational Hypermedia System (AEHS-JS) based on the Overlay Modeling and Felder and Silverman's Learning Styles Model for Job Seekers. International Journal of Emerging Technologies in Learning (iJET), 15(08), 235-254. https://doi.org/10.3991/ijet.v15i08.10574.

Ramlo, S. (2021). The Coronavirus and Higher Education: Faculty Viewpoints about Universities Moving Online during a Worldwide Pandemic. Innovative Higher Education, 1-19. https://doi.org/10.1007/s10755-020-09532-8._

Reigeluth, C. M., Aslan, S., Chen, Z., Dutta, P., Huh, Y., Lee, D., Chun-Yi Lin, Ya-Huei Lu, Mina Min, Verily Tan, Sunnie Lee Watson, William R. Watson \& Watson, S. L. (2015). Personalized integrated educational system: Technology functions for the learner-centered paradigm of education. Journal of Educational Computing Research, 53(3), 459-496. https://doi.org/10.1177/0735633115603998.

Reyes, C. E. G., \& Martínez, R. A. (2021). Competencias digitales para la práctica docente en pregrado en dos universidades latinoamericanas. EDMETIC, 10(1), 1-19.

Rivera, J. A. L., \& Almenara, J. C. (2021). Saberes digitales en el profesorado universitario. Estudio en una escuela mexicana. Revista de Educación a Distancia (RED), 21(66). https://doi.org/10.6018/red.447911.

Rodríguez, M. U., Cantabrana, J. L. L., \& Cervera, M. G. (2021) Validación de una herramienta para autoevaluar la competencia digital docente. Educación XX1, 24(1).

Román, M., \& Murillo, F. J. (2014). Disponibilidad y uso de TIC en escuelas latinoamericanas: incidencia en el rendimiento escolar. Educação e Pesquisa, 40(4), 879-895. http://dx.doi.org/10.1590/s1517-97022014121528.

Rossi, G., Pastor, O., Schwabe, D., \& Olsina, L. (Eds.). (2007). Web engineering: modelling and implementing web applications. Springer Science \& Business Media.

Ruiz-Palmero, J., López-Álvarez, D., \& Sánchez-Rivas, E. (2021). Revisión de la producción científica sobre M00C entre 2016 y 2019 a través de SCOPUS. Pixel-Bit, Revista de Medios y Educacion, (60)

Savage, K., Arif, S., Smoke, M., \& Farrell, T. (2017). Preferences in learning styles and modes of information delivery in patients receiving firstday education for radiation therapy. Journal of medical imaging and radiation sciences, 48(2), 193-198.

https://doi.org/10.1016/j.jmir.2016.10.011.

Selwyn, N. (2016). Education and technology: Key issues and debates. Bloomsbury Publishing.

Torrijos, S., Bellogín, A., \& Sánchez, P. (2020, July). Discovering related users in location-based social networks. In Proceedings of the 28th ACM conference on user modeling, adaptation and personalization (pp. 353-357). https://doi.org/10.1145/3340631.3394882 .

Triana Cordoví, J., \& Galeano Zaldívar, L. (2020). Infraestructura en Cuba: retos para el desarrollo futuro. Economía y Desarrollo, 164(2).

Troussas, C., Chrysafiadi, K., \& Virvou, M. (2020). Personalized tutoring through a stereotype student model incorporating a hybrid learning stvle inctrument Fdlucation and Information Terhnolnaies, 1-13. https://doi.org/10.1007/s10639-020-10366-2.

Loading [MathJax]/jax/output/CommonHTML/fonts/TeX/fontdata.js

Page $11 / 14$ 
UNESCO, U. D. T. (2013). Uso de TIC en educación en América Latina y el caribe. Análisis regional de la integración de las TIC en la educación y de la aptitud digital (e-readiness). Montréal, Instituto de Estadística de la UNESCO.

Vail, A. K., Boyer, K. E., Wiebe, E. N., \& Lester, J. C. (2015, June). The Mars and Venus effect: The influence of user gender on the effectiveness of adaptive task support. In International Conference on User Modeling, Adaptation, and Personalization (pp. 265-276). Springer, Cham. https://doi.org/10.1007/978-3-319-20267-9_22.

Vitali, J., Blackmore, C., \& Bakeberg, M. C. (2021, January). Flexible Teaching and Learning Modalities in Undergraduate Science Amid the COVID-19 Pandemic. In Frontiers in Education. Frontiers Research Foundation.

Wongwatkit, C., Panjaburee, P., Srisawasdi, N., \& Seprum, P. (2020). Moderating effects of gender differences on the relationships between perceived learning support, intention to use, and learning performance in a personalized e-learning. Journal of Computers in Education, 1-27. https://doi.org/10.1007/s40692-020-00154-9.

Yang, B., \& Huang, C. (2021). Turn crisis into opportunity in response to COVID-19: experience from a Chinese University and future prospects. Studies in Higher Education, 46(1), 121-132.

\section{Figures}

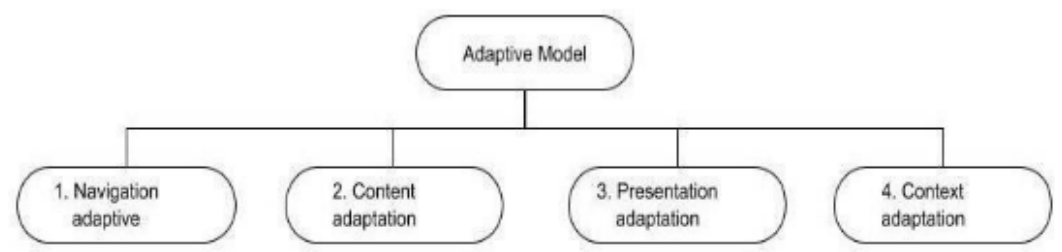

\section{Figure 1}

Adaptive Model. By authors with LibreOffice.

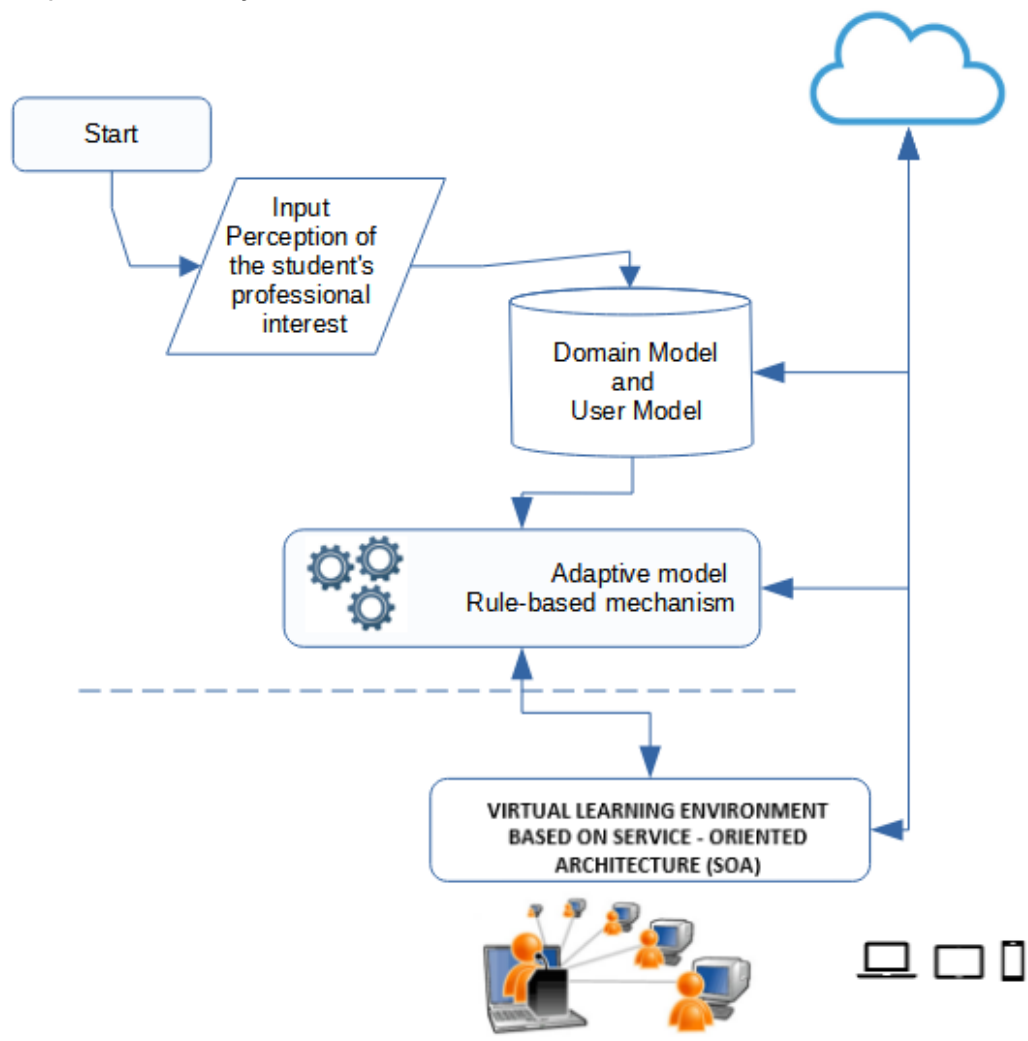

Figure 2 
Conceptual architecture of an Adaptive System integrated with the Virtual Learning Environment based on Service Oriented Architecture (SOA). By authors with LibreOffice.

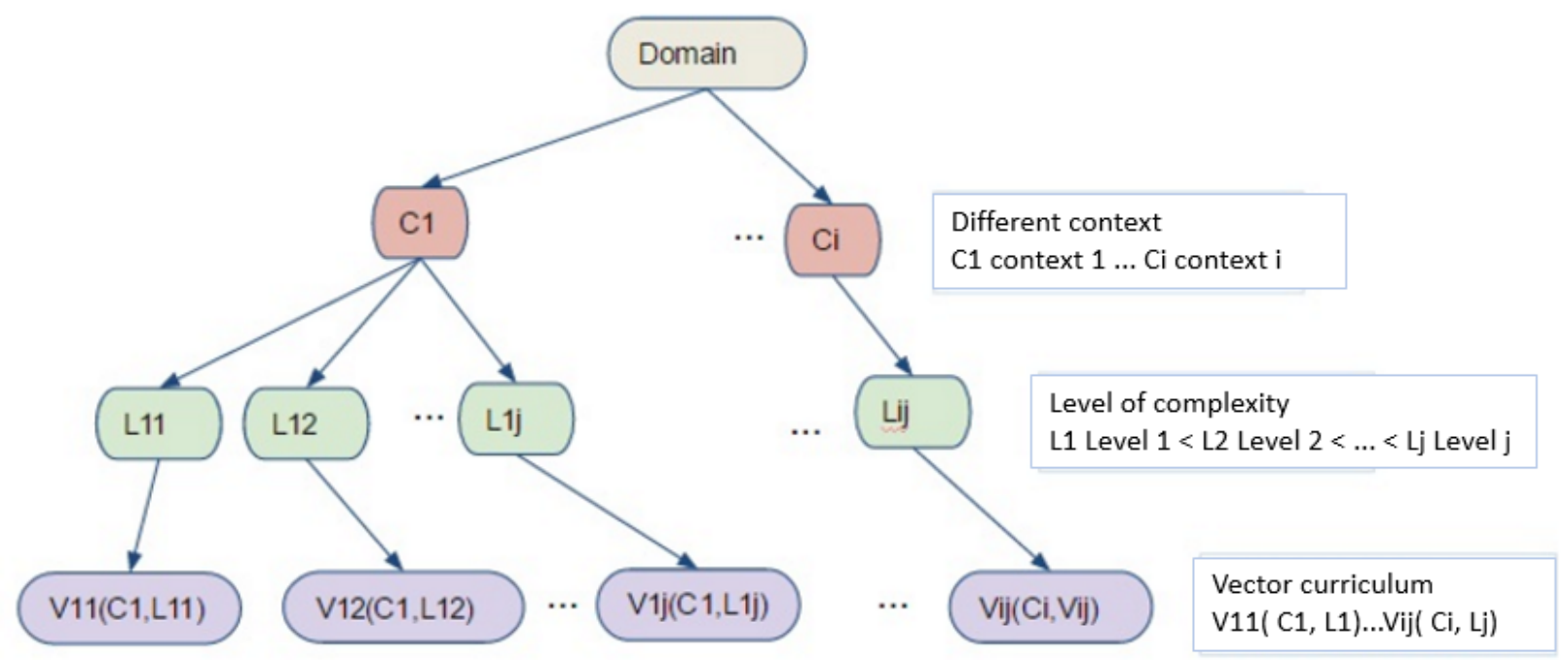

\section{Figure 3}

The domain models. By authors with LibreOffice.
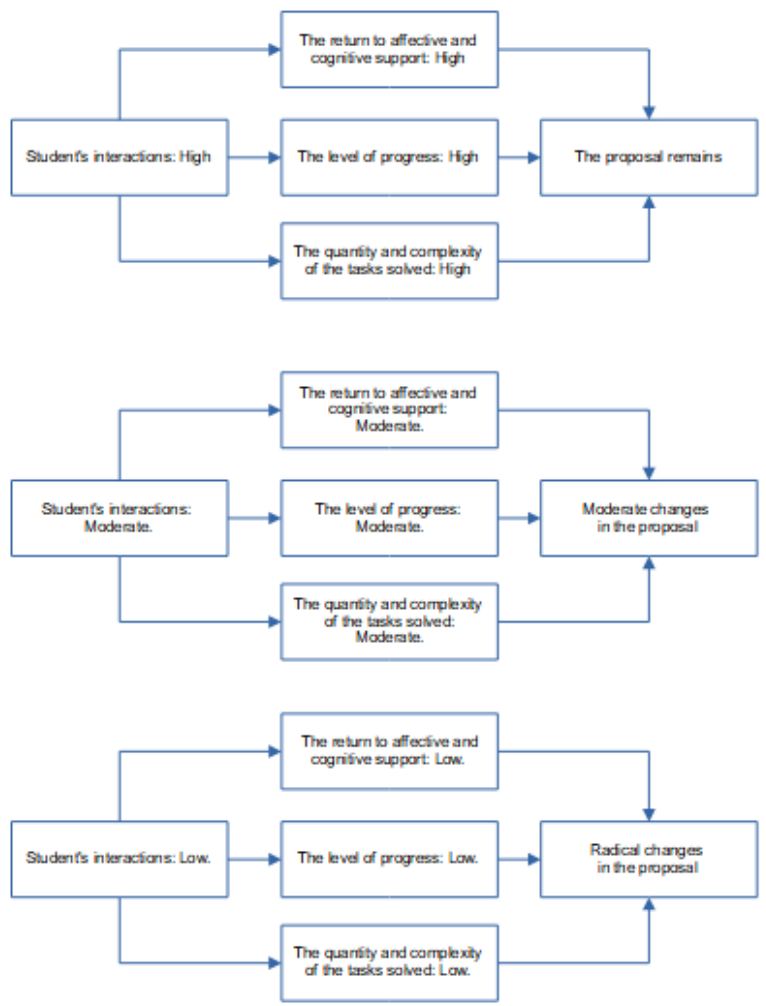

\section{Figure 4}

The basic scheme for the analysis of the adaptation rules. By authors with LibreOffice. 


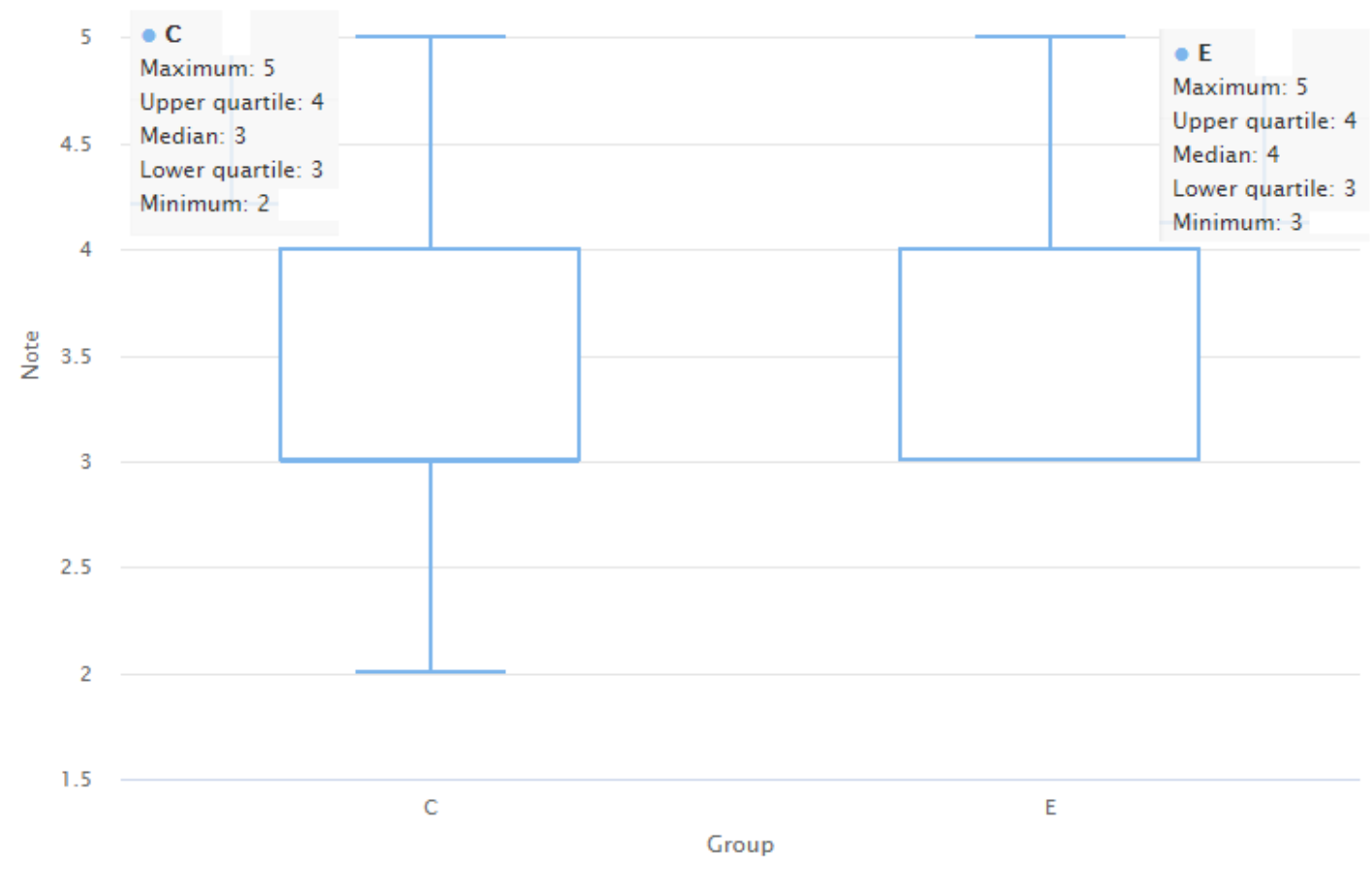

Figure 5

Box plot diagram, representation of academic performance by quartiles. By authors with RapidMiner Studio.

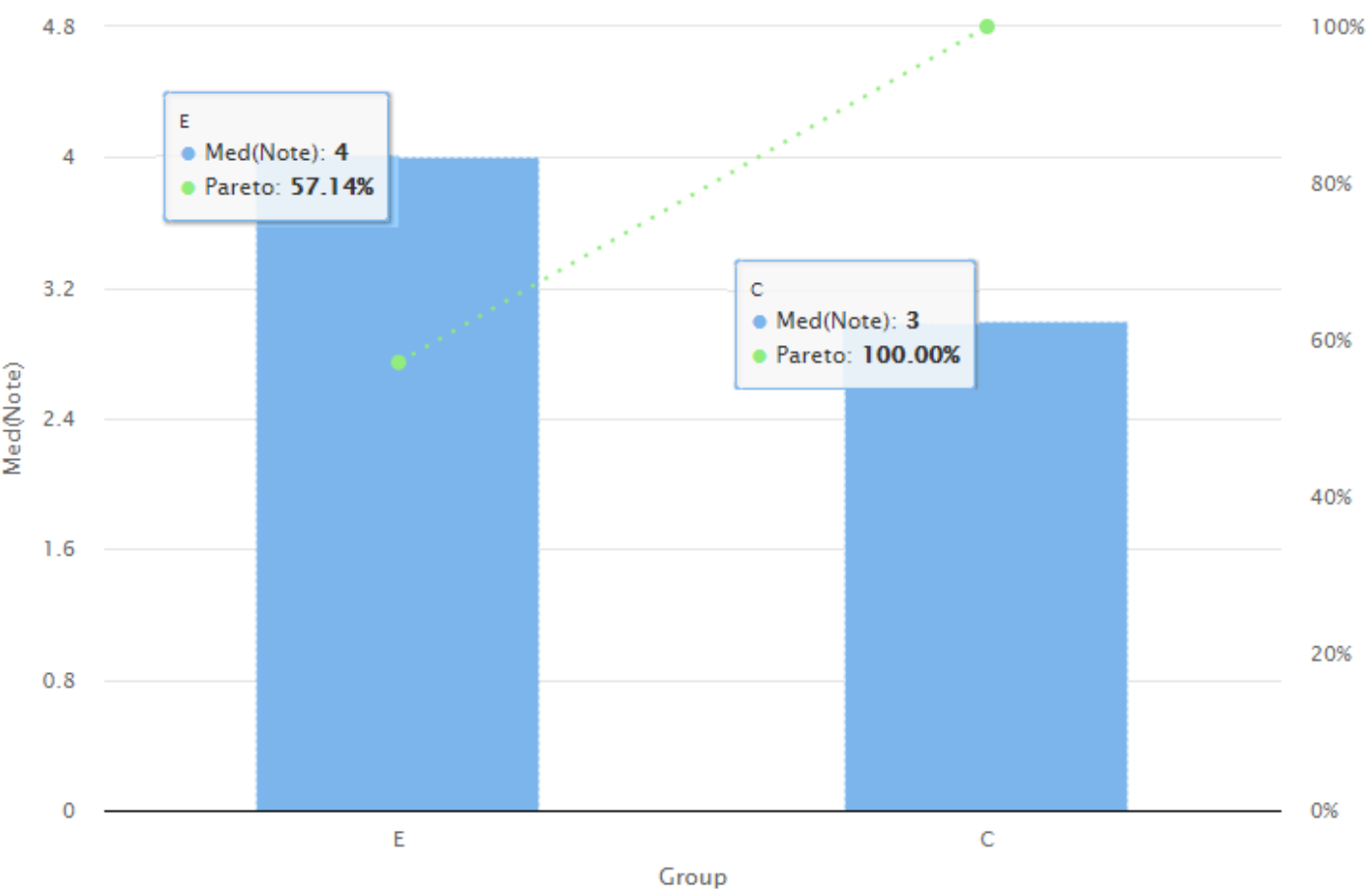

Med(Note)

\section{Figure 6}

Pareto diagram. By authors with RapidMiner Studio. 